\title{
Comparison of Thermal Responses, Reproductive Biologies, and Population Growth Potentials of the Squash Bug Egg Parasitoids Ooencyrtus anasae and $O$. sp. (Hymenoptera: Encyrtidae)
}

\author{
J. L. TRACY AND J. R. NECHOLS \\ Department of Entomology, Kansas State University, \\ Manhattan, Kansas 66506
}

\begin{abstract}
Environ. Entornol. 17(4): 636-643 (1988)
ABSTRACT Laboratory investigations of the gregarious squash bug egg parasitoids Ooencyrt tus anasae (Ashmead) and $O$. sp. were conducted at $20.8,23.0$, and $26.6^{\circ} \mathrm{C}$. Females of both species emerged with undeveloped ovaries. Oöcyte development proceeded during the preovipositional period (ca. $35 \mathrm{~h}$ at $26.6^{\circ} \mathrm{C}$ ) but did not exceed half of the total fecundity at initial oviposition. Preovipositional periods, time to peak oviposition, and time to $75 \%$ oviposition were generally similar for both parasitoids at $20.8^{\circ} \mathrm{C}$. However, reproductive responses differed at temperatures above $20.8^{\circ} \mathrm{C}$. In $O$. anasae, oviposition occurred significantly earlier, and at a similarly higher rate, at 23.0 and $26.6^{\circ} \mathrm{C}$ than at $20.8^{\circ} \mathrm{C}$, whereas significant changes in preovipositional and ovipositional biology of $O$. sp. occurred only after an increase from 23.0 to $26.6^{\circ} \mathrm{C}$. O $\mathrm{sp}$. had a significantly higher fecundity and longer ovipositional period at each temperature than did $O$. anasae. Mean fecundities did not change significantly with increasing temperature. Both parasitoids had an unusually long postreproductive period (ca. $1 \mathrm{mo}$ ) and a longevity of 40 to $50 \mathrm{~d}$. At $26.6^{\circ} \mathrm{C}, O$. sp. had higher gross and net reproductive rates than $O$. anasae. However, $O$. anasae had a shorter generation time (21.4 versus $23.8 \mathrm{~d}$ ) and higher innate capacity for increase (0.146 versus 0.134 ).
\end{abstract}

KEY WORDS Insecta, Ooencyrtus, Anasa tristis, biological control

Comparative evaluations of life history traits of closely related natural enemies are essential for many aspects of developing biological control programs (see DeBach et al. 1976, Gordh 1977, Tauber et al. 1986, Tracy \& Nechols 1987). In addition to these practical applications, interspecific comparisons of key life history traits contribute to our understanding of selective factors underlying the evolution and maintenance of insect life histories (see Stearns [1980], Tauber \& Tauber [1982, 1987], and Price [1984] for examples).

Recently (Tracy \& Nechols 1987), we presented data at various temperatures on the preimaginal biologies and sex ratios of two gregarious egg parasitoids of the squash bug (SB), Anasa tristis DeGeer (Hemiptera: Coreidae)-the encyrtid wasps Ooencyrtus anasae (Ashmead) and $O$. sp.

This study extends the evaluation of these parasitoids by comparing aspects of their adult biologies at various constant temperatures. Specifically, for each parasitoid we determined the preovipositional period, ovipositional schedule (e.g., ovipositional period), ovipositional rate, fecundity, percentage of fertilized females, number of hosts parasitized, and postovipositional period and longevity. In addition, life tables were constructed for each parasitoid at $26.6^{\circ} \mathrm{C}$.

\section{Materials and Methods}

Insect Cultures. SB colonies originated from fieldcollected, overwintered adults. Cultures were reared on potted Cucurbita pepo L. plants using procedures described in Tracy \& Nechols (1987).

Parasitoid colonies were initiated from adults that were collected (or reared) from SB egg masses found in zucchini and pumpkin fields near Manhattan, Kans. Colonies were reared on hosts under the conditions described in Tracy \& Nechols (1987). Voucher specimens of both parasitoid species have been deposited in the entomology research collection at Kansas State University, Manhattan.

Experimental Procedures. All experiments were conducted at three constant temperatures (20.8, 23.0, and $26.6 \pm 0.5^{\circ} \mathrm{C}$ ), $15: 9$ (L:D) photoperiod, and approximately $75 \% \mathrm{RH}$. The specific procedures used are described in Tracy \& Nechols (1987).

To examine the progression of oögenesis, female parasitoids ( $\leq 0.5 \mathrm{~h}$ after emergence) were placed in shell vials with a male and honey and then dissected within an hour of emergence or at the end of the preovipositional period (approximately $35 \mathrm{~h}$ ). The ovarioles in each ovary were inspected for the number of mature oöcytes.

In all other experiments, we used conspecific pairs (female and male) of newly emerged ( $\leq 12 \mathrm{~h}$ old) first and second laboratory-generation adult parasitoids that were reared from parasitized host egg masses. Each pair was placed in a vial containing a $40 \%$ ( $\mathrm{vol} / \mathrm{vol}$ ) honey and water solution and a cluster of five to six SB eggs ( $\leq 24 \mathrm{~h}$ old) on a cut squash leaf. The number of hosts exposed was based on previous observations that females do not parasitize more than six hosts per day. New host 
clusters were exposed daily to each female until about $2 \mathrm{wk}$ after parasitization ceased. Males were removed after about $2 \mathrm{~d}$. A minimum of 11 females was used in all studies.

After exposure, host eggs were examined for parasitization under a dissecting microscope. The presence and number of external parasitoid egg stalks on each intact host were recorded (see Maple [1947] for description). Earlier, we established the relationship between the number of parasitoid egg stalks per host and the number of eggs within the host for each species (Tracy \& Nechols 1987). We used this relationship to estimate the number of eggs laid per female per day of oviposition.

For each individual female, we recorded the first day of oviposition, the number of eggs laid per day, the number of hosts parasitized per day, the number of oviposition days, and the number of days to death. From these data, we computed the preovipositional and ovipositional periods, daily ovipositional and parasitization rates, fecundity, and longevity for each species. We also determined the proportion of mated (fertilized) females of each species in the laboratory by computing the percentage of parasitoids that produced female progeny.

The parasitoids used in all experiments were selected visually for uniformity of body size. Independently, for each species, we established a relationship between female body length and hind tibial length $(\mathrm{mm})$ using the standard linear equation $y=a+b x$, in which $y$ is tibial length, $x$ is body length, $b$ is slope, and $a$ is the $y$-intercept (SAS Institute 1985b). To ensure that body size did not vary between species, we measured hind tibial lengths of females after each experiment. We also tested whether fecundity varied with body size within the range of sizes used in our experiments (see Waage \& Ng 1984). In addition, we measured body lengths of randomly sampled field-collected females of both species.

We constructed life tables for both parasitoids at $26.6^{\circ} \mathrm{C}$ using the preimaginal survivorship, development, and sex ratio data obtained from progeny of mated females (Tracy \& Nechols 1987) and from the daily oviposition and adult survivorship data reported herein. Because all female parasitoids used in this study were reared at $26.6^{\circ} \mathrm{C}$, life tables were not constructed at 20.8 or $23.0^{\circ} \mathrm{C}$. Demographic statistics were calculated using methods described in Birch (1948) and Pielou (1977).

Analysis. The effects of temperature and species on all variables were examined using a two-way analysis of variance (ANOVA) for unbalanced data and Fisher's protected least significant difference test (FPLSD) (SAS Institute 1985b). Data for the preovipositional period and ovipositional schedule were natural log-transformed before analysis.

Percentage data were analyzed by the $\chi^{2}$ test. We tested for correlations between variables using Pearson's product-moment correlation $\left(r_{12}\right)$ test (SAS Institute 1985a).

\section{Results}

Size Relationships. The body lengths of both parasitoid species were significantly correlated with hind tibial lengths $\left(P \leq 0.0001 ; O\right.$. anasae: $r_{12}=$ 0.77 [ $n=25]$; $O$. sp.: $r_{12}=0.84[n=28]$ ) over the range of tibial lengths $(0.352-0.447 \mathrm{~mm})$ found in the experimental parasitoids. Both species had similar regression coefficients ( $O$. anasae: $b=0.352$, $a=-0.015$; $O$. sp.: $b=0.323, a=0.015$ ), which resulted in an interspecific difference in body length of $<2 \%$ for any given tibial length. Mean hind tibial lengths of female parasitoids used in each species-temperature treatment combination were not significantly $(P>0.75$; FPLSD) different.

The estimated mean body length $(\bar{x} \pm \mathrm{SD})$ of female parasitoids used in the experiment was $1.17 \pm 0.07 \mathrm{~mm}(n=61)$. This compares closely with the mean total body lengths of field-collected adult females $(O$. anasae: $1.17 \pm 0.11 \mathrm{~mm}, n=$ 57; O. sp.: $1.13 \pm 0.13 \mathrm{~mm}, n=36$ ).

Oögenesis. Dissections of newly emerged $O$. anasae and $O$. sp. revealed no mature oöcytes within the three ovarioles found in each ovary. At $26.6^{\circ} \mathrm{C}$, the number of mature oöcytes at the end of the preovipositional period (approximately $35 \mathrm{~h}$ ) was $11.8 \pm 5.2(n=9)(\bar{x} \pm \mathrm{SD})$ for $O$. anasae and $8.3 \pm 3.1(n=10)$ for $O$. sp.

Preovipositional Period. The preovipositional periods of both species diminished with increasing temperature (Table 1, column A). However, specific responses to temperature differed for each species. For example, in $O$. anasae, the preovipositional periods at 23.0 and $26.6^{\circ} \mathrm{C}$ were similar and significantly $(P<0.05$; FPLSD) shorter than the preovipositional period at $20.8^{\circ} \mathrm{C}$. Whereas in $O$. sp. the preovipositional periods were similar at the two lower temperatures $\left(20.8\right.$ and $\left.23.0^{\circ} \mathrm{C}\right)$ but were significantly $(\boldsymbol{P}<0.05$; FPLSD) longer than at $26.6^{\circ} \mathrm{C}$. The variances were relatively high in $O$. $\mathrm{sp}$, at the two lower temperatures (Table 1, column A). In addition, $O$. anasae had a significantly $\langle P<$ 0.05 ; FPLSD) shorter preovipositional period at $23.0^{\circ} \mathrm{C}(1.5 \mathrm{~d})$ than $\operatorname{did} O . \mathrm{sp} .(3.8 \mathrm{~d})$.

Ovipositional Schedule. In both species, peak oviposition (defined here as the day that most eggs were laid) occurred significantly ( $P<0.05$; FPLSD) later at $20.8^{\circ} \mathrm{C}$ than at 23.0 or $26.6^{\circ} \mathrm{C}$ (Table 1 , column B), but $O$. anasae had a significantly $(P<$ 0.05 ; FPLSD) earlier day of peak oviposition under all temperatures than did $O$. sp.

The mean day of $75 \%$ egg production ranged from ca. day 8 at $26.6^{\circ} \mathrm{C}$ to day 16 at $20.8^{\circ} \mathrm{C}$ in both parasitoids (Table 1, column C). However, at $23.0^{\circ} \mathrm{C}, 75 \%$ egg production occurred significantly $(P<0.05$; FPLSD) sooner in $O$. anasae (about $7 \mathrm{~d}$ ) than in $O$. sp. (about $15 \mathrm{~d}$ ). In $O$. anasae, there was a significant $(P<0.05$; FPLSD) decrease in the day of $75 \%$ egg production between 20.8 and $23.0^{\circ} \mathrm{C}$, whereas in $O$. sp., a significant $(P<0.05$; FPLSD) decline occurred between 23.0 and $26.6^{\circ} \mathrm{C}$ (Table 1, column C). 
Table 1. Means ( \pm SD) for preovipositional and ovipositional characteristics of the gregarious SB egg parasitoids, Ooencyrtus anasae and $O$. sp, at the indicated temperatures and 15:9 (L:D)

\begin{tabular}{|c|c|c|c|c|c|c|c|c|}
\hline \multirow[t]{2}{*}{$\begin{array}{l}\text { Temp } \\
\left({ }^{\circ} \mathrm{C}\right)^{a}\end{array}$} & \multicolumn{2}{|c|}{$\begin{array}{l}\text { Preovipositional } \\
\text { period (d) } \\
\text { (A) }\end{array}$} & \multicolumn{2}{|c|}{$\begin{array}{c}\text { Day when maximum no. } \\
\text { eggs laid } \\
\text { (B) }\end{array}$} & \multicolumn{2}{|c|}{$\begin{array}{c}\text { Day when } 75 \% \text { eggs laid } \\
\text { (C) }\end{array}$} & \multicolumn{2}{|c|}{$\begin{array}{l}\text { Ovipositional period (d) } \\
\text { (D) }\end{array}$} \\
\hline & O. anasae & O. sp. & O. anasae & $O . \mathrm{sp}$. & O. anasae & $O . \mathrm{sp}$ & O. anasae & $O$. sp. \\
\hline 20.8 & $\begin{array}{c}4.7 \pm 1.2 \mathrm{a} \\
(1-10)\end{array}$ & $\begin{array}{c}5.1 \pm 5.6 \mathrm{a} \\
(1-22)\end{array}$ & $\begin{array}{c}6.6 \pm \\
(3-1\end{array}$ & $\begin{array}{c}9.1 \pm 7.5 b \\
(2-26)\end{array}$ & $9.9 \mathrm{ab}$ & $\begin{array}{r}17.1 \\
\langle 11\end{array}$ & $0.4 b$ & $\begin{array}{r}18.0= \\
(7\end{array}$ \\
\hline 23.0 & $\begin{array}{c}1.5 \pm 1.0 \mathrm{~b} \\
(0-3)\end{array}$ & $\begin{array}{l}3.8 \pm 3.6 a \\
(1-6)\end{array}$ & $\begin{array}{c}3.6 \pm 2.1 c \\
(2-9)\end{array}$ & $\begin{array}{l}6.7 \pm 4.0 \mathrm{~d} \\
\quad(2-14)\end{array}$ & $\begin{array}{l}6.8 \pm 4.2 \mathrm{~d} \\
(2-15)\end{array}$ & $\begin{array}{c}15.1 \pm 4.3 \mathrm{a} \\
(9-25)\end{array}$ & $\begin{array}{c}8.2 \pm 5.9 b \\
(3-14)\end{array}$ & $\begin{array}{c}18.1 \pm 12.5 \mathrm{a} \\
(1-46)\end{array}$ \\
\hline 26.6 & $\begin{array}{c}1.4 \pm 0.9 b \\
(0-3)\end{array}$ & $\begin{array}{l}0.8 \pm 0.6 b \\
(0-2)\end{array}$ & $\begin{array}{l}4.1 \pm 2.1 c \\
(2-10)\end{array}$ & $\begin{array}{l}4.8 \pm 3.7 \mathrm{~d} \\
(2-13)\end{array}$ & $\begin{array}{l}7.1 \pm 2.2 \mathrm{~cd} \\
(3-11)\end{array}$ & $\begin{array}{l}9.5 \pm 2.9 b c \\
(4-13)\end{array}$ & $\begin{array}{c}7.1 \pm 1.9 b \\
(4-10)\end{array}$ & $\begin{array}{c}16.0 \pm 6.2 a \\
(11-33)\end{array}$ \\
\hline
\end{tabular}

All means followed by a different letter are significantly different $(P<0.05$, FPLSD; SAS Institute [1985b]). Numbers in parentheses are ranges of value.

${ }^{a}$ Number of parent females per temperature $\left(20.8-26.6^{\circ} \mathrm{C}\right)$ are as follows: $O$. anasae: 14,12 , and $14 ; 0$. sp.: 13,11 , and 12 .

The mean total ovipositional period (first to last day of oviposition) was significantly $(P<0.05$; FPLSD) longer in $O$. sp. (range of means, 16.0$18.0 \mathrm{~d}$ ) than in $O$. anasae (range of means, 7.1$15.5 \mathrm{~d}$ ) at all temperatures (Table 1, column D). Temperature did not significantly affect the ovipositional period of either species.

Ovipositional Rate. The mean daily ovipositional rates during the first week were similar (about two to four eggs per day) for both species (Table 2 , column A). On the other hand, the ovipositional rates during week 2 were significantly $(P<0.05$; FPLSD) higher in $O$. sp. at each temperature (about two to three eggs per day) than in $O$. anasae (about one egg per day) (Table 2, column B).

The ovipositional rates increased significantly $(P<0.05 ;$ FPLSD $)$ with increasing temperature in both species during the first week of adult life (Table 2, column A). During week 2, no such relationship was observed (Table 2, column B).

The mean daily ovipositional rates followed a cyclic pattern in both species, with peaks in oviposition occurring every 3-6 d. However, in $O$. anasae, considerably fewer cycles occurred at 23.0 and $26.6^{\circ} \mathrm{C}$ than in $O$. sp.

Percentage of Fertilized Females. The percentage of fertilized females (i.e., those producing at least one female progeny) was significantly $(P<$ $0.001, \chi^{2}=37.8 ; \chi^{2}$ test) higher in O. anasae ( $98 \%$ $[n=59])$ than in O. sp. $(43 \%[n=35])$.

Fecundity. The mean total fecundities were significantly $(P<0.01$; FPLSD) higher in $O$. sp. at each temperature (range of means, 40-52 eggs) than in $O$. anasae (range of means, 24-32 eggs) (Table 2, column C). In $O$. sp., the fecundity of unmated females that produced all-male progeny did not differ significantly at any temperature $(P>$ 0.24 ; ANOVA) from that of parasitoids producing some female progeny. Temperature did not significantly affect the fecundity of either species, although the fecundities tended to increase as temperature increased.

Over the relatively narrow size range of parasitoids used in this study (see Size Relationships), fecundity was not significantly $\left(P>0.05 ; r_{12} \leq\right.$ $0.56)$ correlated with hind tibial length for either species. However, there was a strong positive correlation between fecundity and the length of the ovipositional period in $O$. sp. at $20.8^{\circ} \mathrm{C}(P=0.01$; $\left.r_{12}=0.71\right)$ and $23.0^{\circ} \mathrm{C}\left(P=0.0002 ; r_{12}=0.90\right)$; but not at $26.6^{\circ} \mathrm{C}\left(P=0.13 ; r_{12}=0.48\right)$. In contrast, the fecundity of $O$. anasae was not significantly correlated with the ovipositional period $(P \geq 0.06$; $\left.r_{12} \leq 0.54\right)$ at any temperature. In both species,

Table 2. Mean ( \pm SD) daily ovipositional rates and fecundities of the gregarious SB egg parasitoids, Ooencyrtus anasae and $O$. sp., at the indicated temperatures and $15: 9$ (L:D)

\begin{tabular}{|c|c|c|c|c|c|c|}
\hline \multirow{3}{*}{$\begin{array}{l}\text { Temp } \\
\left({ }^{\circ} \mathrm{C}\right)^{a}\end{array}$} & \multicolumn{4}{|c|}{ No. eggs laid per d } & \multirow{2}{*}{\multicolumn{2}{|c|}{$\begin{array}{l}\text { Fecundity } \\
\text { (C) }\end{array}$}} \\
\hline & \multicolumn{2}{|c|}{$\begin{array}{l}\text { First week } \\
\text { (A) }\end{array}$} & \multicolumn{2}{|c|}{$\begin{array}{l}\text { Second week } \\
\text { (B) }\end{array}$} & & \\
\hline & O. anasae & O. sp. & O. anasae & O. sp. & O. anasae & $O . \mathbf{s p}$ \\
\hline 20.8 & $\begin{array}{c}1.6 \pm 1.3 \mathrm{c} \\
(0-4.4)\end{array}$ & $\begin{array}{c}1.7 \pm 1.5 \mathrm{c} \\
(0-4.4)\end{array}$ & $\begin{array}{c}1.1 \pm 1.0 \mathrm{~b} \\
(0-3.0)\end{array}$ & $\begin{array}{c}2.1 \pm 1.2 \mathrm{a} \\
(0-4.2)\end{array}$ & $\begin{array}{c}23.9 \pm 10.3 a \\
(12-46)\end{array}$ & $\begin{array}{c}40.5 \pm 19.4 b \\
(17-77)\end{array}$ \\
\hline 23.0 & $\begin{array}{l}3.1 \pm 1.8 b \\
(1.2-7.2)\end{array}$ & $\begin{array}{c}2.5 \pm 1.7 \mathrm{~b} \\
(0-4.8)\end{array}$ & $\begin{array}{c}0.5 \pm 0.9 \mathrm{~b} \\
(0-3.1)\end{array}$ & $\begin{array}{c}2.9 \pm 1.6 \mathrm{a} \\
(0.5-5.5)\end{array}$ & $\begin{array}{c}28.0 \pm 14.2 \mathrm{a} \\
(8-52)\end{array}$ & $\begin{array}{c}53.6 \pm 27.9 b \\
\quad(3-96)\end{array}$ \\
\hline 26.6 & $\begin{array}{l}3.7 \pm 2.0 \mathrm{a} \\
(1.1-6.5)\end{array}$ & $\begin{array}{l}4.3 \pm 1.1 \mathrm{a} \\
(3.0-6.6)\end{array}$ & $\begin{array}{c}0.9 \pm 1.1 b \\
(0-3.9)\end{array}$ & $\begin{array}{c}2.9 \pm 1.7 \mathrm{a} \\
(0-5.0)\end{array}$ & $\begin{array}{c}32.2 \pm 13.3 \mathrm{a} \\
(10-49)\end{array}$ & $\begin{array}{c}51.8 \pm 21.0 \mathrm{~b} \\
(28-90)\end{array}$ \\
\hline
\end{tabular}

All means followed by a different letter are significantly different $(P<0.05$, FPLSD; SAS Institute [1985b]). Numbers in parentheses are ranges of values.

${ }^{a}$ Number of parent females per temperature $\left(20.8-26.6^{\circ} \mathrm{C}\right)$ are as follows: $O$. anasae: 14,12 , and $14 ; 0 . s p .: 13,11$, and 12 
Table 3. Mean ( \pm SD) total number of hosts parasitized, postovipositional periods, and longevities of the gregarious SB egg parasitoids, Ooencyrtus anasae and $O$. sp., at the indicated temperatures and 15:9 (L:D)

\begin{tabular}{|c|c|c|c|c|c|c|}
\hline \multirow{2}{*}{$\begin{array}{l}\text { Temp } \\
\left({ }^{\circ} \mathrm{C}\right)\end{array}$} & \multicolumn{2}{|c|}{$\begin{array}{l}\text { Total no. hosts parasitized } \\
\text { (A) }\end{array}$} & \multicolumn{2}{|c|}{$\begin{array}{l}\text { Postovipositional period (d) } \\
\text { (B) }\end{array}$} & \multicolumn{2}{|c|}{$\begin{array}{l}\text { Longevity (d) } \\
\text { (C) }\end{array}$} \\
\hline & O. anasae & $O . \mathrm{sp}$ & O. anasae & O. sp. & O. anasae & $O . \mathrm{sp}$ \\
\hline 20.8 & $\begin{array}{l}7.9 \pm 4.2 a \\
(14)[3-16]\end{array}$ & $\begin{array}{l}12.4 \pm 5.8 \mathrm{~b} \\
\text { (13) }[5-23]\end{array}$ & $\begin{array}{l}42.9 \pm 21.6 \mathrm{a} \\
(12)[0-81]\end{array}$ & $\begin{array}{l}26.8 \pm 19.9 a \\
(10)[1-62]\end{array}$ & $\begin{array}{l}62.7 \pm 20.4 a \\
(12)[15-92]\end{array}$ & $\begin{array}{l}50.7 \pm 20.2 \mathrm{a} \\
(10)[21-84]\end{array}$ \\
\hline 23.0 & $\begin{array}{l}8.2 \pm 3.9 a \\
(12)[3-14]\end{array}$ & $\begin{array}{l}15.6 \pm 7.7 \mathrm{~b} \\
\text { (11) }[1-27]\end{array}$ & $\begin{array}{l}38.2 \pm 15.6 \mathrm{a} \\
(9)[6-57]\end{array}$ & $\begin{array}{l}33.0 \pm 14.1 \mathrm{a} \\
(10)[8-54]\end{array}$ & $\begin{array}{c}49.2 \pm 12.2 \mathrm{a} \\
(9)[24-68]\end{array}$ & $\begin{array}{l}54.5 \pm 14.6 \mathrm{a} \\
(10)[25-69]\end{array}$ \\
\hline 26.6 & $\begin{array}{l}9.4 \pm 4.3 a \\
(14)[3-16]\end{array}$ & $\begin{array}{l}14.5 \pm 6.5 b \\
(12)[8-27]\end{array}$ & $\begin{array}{l}31.9 \pm 16.3 \mathrm{a} \\
\text { (13) }[1-52]\end{array}$ & $\begin{array}{l}32.7 \pm 10.8 a \\
(11)[6-46]\end{array}$ & $\begin{array}{l}40.6 \pm 16.3 \mathrm{a} \\
(13)[9-61]\end{array}$ & $\begin{array}{l}49.8 \pm 11.7 \mathrm{a} \\
(11)[22-60]\end{array}$ \\
\hline
\end{tabular}

All means followed by a different letter are significantly different $(P<0.05$; FPLSD; SAS Institute [1985b]). Numbers in parentheses are the numbers of females observed; numbers in brackets are the ranges of values.

fecundity was not significantly correlated $(P \geq 0.28$ $r_{12} \leq 0.32$ ) with longevity at any temperature.

Host Parasitization. Both species parasitized three or four hosts (range, 1-6) on the day of peak parasitization. These values were not influenced by temperature.

The total number of hosts parasitized during the lifetime of a female parasitoid was significantly $(P<0.01$; FPLSD) higher in $O$. sp. than in $O$. anasae at all temperatures (Table 3 , column A). In both parasitoids, the total number of hosts parasitized was unrelated to temperature.

Postovipositional Period and Longevity. The mean postovipositional period for both parasitoids was at least 1 mo at each temperature (Table 3, column B), but in both species the period was highly variable.

Longevity tended to decrease with increasing temperature in $O$. anasae but not in $O$. sp. (Table 3 , column C). However, these trends were not significant, and no statistical differences were found in longevity between species.

Life Tables. During the first $1.5 \mathrm{wk}$ of adult life (about days 18-26), the mean number of female progeny produced per day $\left(m_{x}\right)$ and the daily percentage contribution to the innate capacity for increase ( $r \%$ ) (Table 4) were generally higher in $O$. anasae than in $O$. sp. Thereafter, both statistics were consistently higher in $O$. $\mathrm{sp}$. The cumulative percentage contribution to the innate capacity for

Table 4. Life tables including daily and cumulative percentage contributions to the innate capacity for increase ( $\left.r_{m}\right)$ for Ooencyrtus anasae and $O$. sp. at $26.6^{\circ} \mathrm{C}$ and $15: 9$ (L:D)

\begin{tabular}{|c|c|c|c|c|c|c|c|c|c|c|c|c|c|}
\hline \multirow{2}{*}{ Stage } & \multirow{2}{*}{$n$} & \multicolumn{6}{|c|}{ O. anasae } & \multicolumn{6}{|c|}{ O. sp. } \\
\hline & & $x$ & $l_{x}$ & $f e c_{x}$ & $m_{x}$ & $+\%$ & $\Sigma r \%$ & $x$ & $l_{x}$ & $f e c_{x}$ & $m_{x}$ & $r \%$ & $\Sigma \mathrm{r} \%$ \\
\hline \multirow{23}{*}{$\begin{array}{l}\text { Egg-larva } \\
\text { Pharate adult } \\
\text { Adult }\end{array}$} & & \multirow{2}{*}{$1-17$} & 1.00 & 0.00 & 0.00 & 0.00 & 0.00 & \multirow{2}{*}{$1-18$} & 1.00 & 0.00 & 0.00 & 0.00 & 0.00 \\
\hline & & & 0.90 & 0.00 & 0.00 & 0.00 & 0.00 & & 0.90 & 0.00 & 0.00 & 0.00 & 0.00 \\
\hline & I & 18.0 & 0.88 & 0.51 & 0.41 & 2.62 & 2.62 & 19.0 & 0.86 & 1.95 & 1.09 & 7.31 & 7.31 \\
\hline & 2 & 19.0 & 0.88 & 3.94 & 3.19 & 17.51 & 20.13 & 20.0 & 0.86 & 7.56 & 4.23 & 24.79 & 32.10 \\
\hline & 3 & 20.0 & 0.88 & 9.37 & 7.59 & 35.98 & 56.11 & 21.0 & 0.86 & 6.18 & 3.46 & 17.71 & 49.82 \\
\hline & 4 & 21.0 & 0.88 & 4.52 & 3.66 & 15.00 & 71.10 & 22.0 & 0.86 & 3.80 & 2.13 & 9.52 & 59.34 \\
\hline & 5 & 22.0 & 0.88 & 3.07 & 2.49 & 8.80 & 79.92 & 23.0 & 0.86 & 4.79 & 2.68 & 10.50 & 69.84 \\
\hline & 6 & 23.0 & 0.88 & 2.26 & 1.83 & 5.60 & 85.51 & 24.0 & 0.86 & 1.73 & 0.97 & 3.31 & 73.15 \\
\hline & 7 & 24.0 & 0.88 & 2.19 & 1.77 & 4.69 & 90.20 & 25.0 & 0.86 & 2.05 & 1.15 & 3.43 & 76.58 \\
\hline & 8 & 25.0 & 0.88 & 2.33 & 1.89 & 4.31 & 94.51 & 26.0 & 0.86 & 4.70 & 2.63 & 6.88 & 83.47 \\
\hline & 9 & 26.0 & 0.81 & 1.53 & 1.24 & 2.25 & 96.76 & 27.0 & 0.86 & 5.25 & 2.94 & 6.72 & 90.19 \\
\hline & 10 & 27.0 & 0.81 & 1.89 & 1.53 & 2.40 & 99.16 & 28.0 & 0.86 & 2.32 & 1.30 & 2.60 & 92.78 \\
\hline & 11 & 28.0 & 0.81 & 0.25 & 0.20 & 0.28 & 99.44 & 29.0 & 0.86 & 1.13 & 0.63 & 1.11 & 93.88 \\
\hline & 12 & 29.0 & 0.81 & 0.59 & 0.48 & 0.56 & 100.00 & 30.0 & 0.86 & 1.65 & 0.92 & 1.41 & 95.30 \\
\hline & 13 & 30.0 & 0.81 & 0.00 & 0.00 & 0.00 & 100.00 & 31.0 & 0.86 & 3.58 & 2.00 & 2.68 & 97.98 \\
\hline & 14 & 31.0 & 0.81 & 0.00 & 0.00 & 0.00 & 100.00 & 32.0 & 0.86 & 1.16 & 0.65 & 0.76 & 98.74 \\
\hline & 15 & 32.0 & 0.81 & 0.00 & 0.00 & 0.00 & 100.00 & 33.0 & 0.86 & 0.25 & 0.14 & 0.14 & 98.88 \\
\hline & 16 & 33.0 & 0.75 & 0.00 & 0.00 & 0.00 & 100.00 & 34.0 & 0.86 & 1.09 & 0.61 & 0.55 & 99.42 \\
\hline & 17 & 34.0 & 0.75 & 0.00 & 0.00 & 0.00 & 100.00 & 35.0 & 0.86 & 1.09 & 0.61 & 0.48 & 99.90 \\
\hline & . & & & & & & & & & & & & \\
\hline & 21 & 38.0 & 0.75 & 0.00 & 0.00 & 0.00 & 100.00 & 39.0 & 0.77 & 0.40 & 0.22 & 0.10 & 99.99 \\
\hline & . & & & & & & & & & & & & \\
\hline & 34 & 51.0 & 0.63 & 0.00 & 0.00 & 0.00 & 100.00 & 52.0 & 0.77 & 0.21 & 0.11 & 0.01 & 100.00 \\
\hline
\end{tabular}

See Table 5 for $r_{m}$ and other demographic statistics. The reproductive schedule as obtained from 14 female $O$, anasae and 11 female $O$. sp. Life table parameters: $p$, proportion of females among all progeny, 0.81 for $O$. anasae, $0.54 \mathrm{for} O$. sp.; $n$, day of adult life; $\boldsymbol{x}$, age interval $(\mathrm{d}) ; l_{x}$, proportion of females surviving to start of age interval $x\left(l_{0}=1.00\right)$; $f e c_{x}$, no. of offspring produced per age interval per female alive at age $x ; m_{x} f e c_{x}(p) ; r \%$, the daily percentage contribution to the innate capacity for increase $\left(r_{m}\right),\left[\left(e^{-r(x)}\right) l_{x} m_{x}\right)(100)$; sr\%, cumulative $r \%$. 
Table 5. Net reproductive rate $\left(R_{0}\right)$, mean generation time $(T)$, innate eapacity $\left(r_{m}\right)$ or capacity $\left(r_{c}\right)$ for increase $(r)$, and population doubling time $(D T)$ for various hymenopterous egg parasitoids at the specified temperatures

\begin{tabular}{|c|c|c|c|c|c|c|}
\hline Egg parasitoid & $\begin{array}{l}\text { Temp } \\
\left({ }^{\circ} \mathrm{C}\right)\end{array}$ & $R_{0}$ & $T$ & $r$ & $D T$ & Reference \\
\hline \multicolumn{7}{|l|}{ I. Chalcidoidea } \\
\hline \multicolumn{7}{|l|}{ A. Encyrtidae } \\
\hline $\begin{array}{l}\text { Ooenctyrtus anasae } \\
O . \mathrm{sp} .\end{array}$ & $\begin{array}{l}26.6 \\
26.6\end{array}$ & $\begin{array}{l}22.9 \\
24.5\end{array}$ & $\begin{array}{l}21.4 \\
23.8\end{array}$ & $\begin{array}{l}0.146 \\
0.134\end{array}$ & $\begin{array}{l}4.8 \\
5.2\end{array}$ & $\begin{array}{l}\text { Present study } \\
\text { Present study }\end{array}$ \\
\hline \multicolumn{7}{|l|}{ B. Trichogrammatidae } \\
\hline $\begin{array}{l}\text { Trichogramma retorridum } \\
\text { T. pretiosum } \\
\text { T. brevicapillum } \\
\text { T. minutum } \\
\text { T. platneri } \\
T \text {. dendrolimi }\end{array}$ & $\begin{array}{l}25.0 \\
25.0 \\
25.0 \\
27.0 \\
27.0 \\
30.0\end{array}$ & $\begin{array}{l}54.5 \\
50.0 \\
66.9 \\
- \\
- \\
-\end{array}$ & $\begin{array}{r}14.4 \\
11.5 \\
12.9 \\
8.9 \\
9.5 \\
-\end{array}$ & $\begin{array}{l}0.277 \\
0.34 \\
0.33 \\
0.43 \\
0.37 \\
0.604\end{array}$ & $\begin{array}{l}2.5 \\
2.0 \\
2.1 \\
1.6 \\
1.9 \\
1.1\end{array}$ & $\begin{array}{l}\text { Orphanides \& Gonzalez } 1971 \\
\text { Pak \& Oatman } 1982 \\
\text { Pak \& Oatman } 1982 \\
\text { Manweiler } 1986 \\
\text { Manweiler } 1986 \\
\text { Hirose } 1986\end{array}$ \\
\hline \multicolumn{7}{|l|}{ C. Eupelmidae } \\
\hline $\begin{array}{l}\text { Anastatus japonicus } \\
\text { A. semiflavidus }\end{array}$ & $\overline{25.0}$ & $\overline{90.1}$ & $\overline{57.2}$ & $\begin{array}{l}0.149 \\
0.079\end{array}$ & $\begin{array}{l}4.7 \\
8.8\end{array}$ & $\begin{array}{l}\text { Hirose } 1986 \\
\text { Mendel et al. } 1987\end{array}$ \\
\hline \multicolumn{7}{|l|}{ D. Mymaridae } \\
\hline Anagrus epos & 28.0 & 20.2 & 14.4 & 0.165 & 4.2 & Williams 1984 \\
\hline \multicolumn{7}{|l|}{ II. Proctotrupoidea } \\
\hline \multicolumn{7}{|l|}{ A. Scelionidae } \\
\hline $\begin{array}{l}\text { Telenomus calvus } \\
T . \text { basalis } \\
T . \text { dendrolimi } \\
T . \text { podisi }\end{array}$ & $\begin{array}{l}27.0 \\
- \\
30.0 \\
27.0\end{array}$ & $\begin{array}{l}- \\
- \\
-\end{array}$ & $\begin{array}{l}- \\
- \\
-\end{array}$ & $\begin{array}{l}0.149 \\
0.315 \\
0.296 \\
0.308\end{array}$ & $\begin{array}{l}4.7 \\
2.2 \\
2.3 \\
2.3\end{array}$ & $\begin{array}{l}\text { Orr et al. } 1986 \\
\text { Orr et al. } 1986 \\
\text { Hirose } 1986 \\
\text { Orr \& Boethel } 1986\end{array}$ \\
\hline
\end{tabular}

$R_{0}$, females/female/lifetime; $T$, days; $r$, females/female/day; $D T$, days.

increase $(\Sigma r \%)$ by $O$. anasae was consistently higher than that of $O$. sp., especially toward the end of the first week of adult life (between days 20 and 25) (Table 4).

The net reproductive rate $\left(R_{0}\right)$ of $O$. sp. was higher than in $O$. anasae (Table 5), whereas the mean generation time $(T)$ was shorter, and the innate capacity for increase $\left(r_{m}\right)$ higher, in $O$. anasae (Table 5).

\section{Discussion}

Ö̈genesis. No oöcytes were mature upon adult emergence, whereas the number of mature oöcytes at the end of the preovipositional periods (approximately $35 \mathrm{~h}$ ) represented less than $50 \%$ of the total fecundities for both species. Therefore, most of the oöcytes mature after oviposition has begun. This suggests that both parasitoids have a synovigenic mode of reproduction, which is common to many of the Encyrtidae. Females exhibiting synovigenic reproduction can store or resorb (or both) eggs in relation to host availability (see Flanders 1950).

Our findings compare with those of Maple (1937) for Ooencyrtus johnsoni (Howard), in which the first mature oöcytes appeared about $12 \mathrm{~h}$ after emergence at $25.6^{\circ} \mathrm{C}$.

Preovipositional Period. Interspecific differences in the influence of temperature on the preovipositional period are probably related to the effect of temperature on the rate of oögenesis in adult egg parasitoids. Laraichi (1979) suggested that temperature-dependent differences in rates of oögenesis were responsible for variation in the preovi- positional periods of three Ooencyrtus spp. that parasitize eggs of a pentatomid, Aelia cognata Fieber. On the other hand, only slight temperaturerelated differences in the preovipositional periods were found among three Encarsia spp. (Aphelinidae) that attack the greenhouse whitefly, Trialeurodes vaporariorum (Westwood) (Aleyrodidae) (van Lenteren \& van der Schaal 1981).

Ovipositional Schedule. Differences in the influence of temperature on the ovipositional schedules of Ooencyrtus are similar to those observed for the preovipositional period (Table 1). This suggests that the two species may have different thermal optima governing the rate and duration of oögenesis.

Ovipositional Rate. In both parasitoids, the daily number of eggs deposited varied in cycles of 3$6 \mathrm{~d}$ (see Tracy 1987). These ovipositional patterns may represent synchronized cycles of oöcyte maturation in the female parasitoids. However, these findings differ from those reported for other Ooencyrtus spp. in which the ovipositional rates were acyclic (Laraichi 1979, Herard \& Mercadier 1980, Alzofon 1984). On the other hand, the fluctuating cycle of egg production has been observed in another gregarious encyrtid, the spherical mealybug parasitoid Anagyrus indicus Shafee et al. (J.R.N., unpublished data).

Percentage of Fertilized Females. A relatively high percentage $(57 \%)$ of the $O$. sp. females produced only male progeny; this compares with about $2 \%$ in $O$. anasae. Because both species are arrhenotokous, these data suggest that many of the $O$. sp. females did not mate in the laboratory and depos- 
ited unfertilized eggs. It is interesting to note that the percentage of female progeny emerging from field-collected hosts for both parasitoids was the same as that observed among progeny of mated females in the laboratory (Tracy \& Nechols 1987). This implies that most females in the field are mated. Thus, it is possible that our laboratory conditions were relatively less favorable for mating in O. sp.

Fecundity. Neither fecundity nor any of the other biological characteristics we evaluated were influenced by mating status in $O$. sp. Therefore, interspecific differences in fecundity between the two parasitoids are probably unrelated to the proportion of mated females in our study. Our findings are supported by investigations of several other Ooencyrtus species for which no relationship between fecundity and mating status was found (Maple 1937, Laraichi 1979, Fedde 1982). However, Crossman (1925) found that unmated females of the gypsy moth egg parasitoid, Ooencyrtus kuvanae (Howard), produced fewer progeny than mated females.

Fecundity was significantly and positively correlated with the duration of the ovipositional period in $O$. sp. at 20.8 and $23.0^{\circ} \mathrm{C}$, but there was no significant correlation between fecundity and longevity at any of the temperatures in either species. All of these findings generally agree with those reported for three other Ooencyrtus species (Laraichi 1979).

The higher fecundity in $O$. sp. may be related to a relatively higher rate of oögenesis during the second week of adult life. In synovigenic parasitoids, oögenesis has been linked with adult feeding on protein-containing host fluids that exude from the ovipositional wound of a potential host (i.e., host feeding) (see Flanders 1950, Jervis \& Kidd 1986, van Lenteren et al. 1987). Although we have observed host feeding in both parasitoids (and considerably more so in $O$. sp.), we do not know whether differences in protein intake of the two species are related to differences in oögenesis or to total fecundity in the laboratory.

The mean total fecundities of $O$. anasae (32 eggs) and $O$. sp. (52 eggs) at $26.6^{\circ} \mathrm{C}$ are at the lower end of the range of total eggs (or progeny) produced by other Ooencyrtus spp. that have been studied (36-135 under similar temperature conditions [Crossman 1925, Maple 1937, Laraichi 1979, Matteson 1981, Fedde 1982]). The relatively low fecundities of the species we studied may reflect the very high field eclosion rates observed for SB eggs (Beard 1940, unpublished data), and the very high total survivorship of both Ooencyrtus spp. (Tracy \& Nechols 1987). The solitary SB egg parasitoid, Gryon pennsylvanicum (Ashmead), appears to have a much higher fecundity (approximately 90 eggs) than do these Ooencyrtus spp. (G. F. Fedde, personal communication; J.R.N., unpublished data).

Host Parasitization. Both species showed a limited capacity to attack hosts in the laboratory. For example, each female parasitized an average of only 3-4 SB eggs a day. In addition, lifetime parasitization rates of these gregarious parasitoids were only 8-16 hosts on the average (Table 3, column A). This figure is low compared with the approximately 240 eggs deposited by the squash bug in the field (Beard 1940) during about 2 mo of oviposition (Beard 1940, Nechols 1987).

Postovipositional Period and Longevity. In the laboratory, females of both species had very long postreproductive periods (about $1 \mathrm{mo}$ ) that were associated with high longevities (Table 3 , columns $\mathrm{B}$ and $\mathrm{C}$ ). At $26.6^{\circ} \mathrm{C}$, the mean longevities of females of both parasitoids (about 40-50 d) are higher than those reported for six other Ooencyrtus spp. (20-33 d) at comparable temperatures (Laraichi 1979, Lee 1979, Matteson 1981, Fedde 1982). They also are higher than the longevity of female $O$. kuvanae, which live $30-42 \mathrm{~d}$ (Crossman 1925, Weseloh 1986).

The high longevity of these parasitoids, in conjunction with a synovigenic mode of reproduction, suggests that they may be able to delay reproduction for prolonged periods in the absence of hosts (see Flanders 1950). Delayed reproduction in the absence of hosts has been observed in several other Ooencyrtus spp. that are apparently synovigenic (see Laraichi 1978, Weseloh 1986). Ooencyrtus submetallicus (Howard) is known to extend its longevity in the absence of hosts (Lee 1979).

Life Tables. $O$. sp. had a higher net reproductive rate $\left(R_{0}\right)$ than $O$. anasae. However, $O$. anasae had a shorter mean generation time $(T)$ and higher innate capacity for increase $\left(r_{m}\right)$. We attribute the higher $R_{0}$ of $O$. sp. to its higher fecundity (Table 5 ). The higher percentage of female progeny produced by $O$. anasae compared with mated $O$. sp. (Tracy \& Nechols 1987) resulted in the production of a relatively higher number of female progeny per day $\left(m_{x}\right)$ early in adult life. This contributed to a shorter mean generation time (hence higher innate capacity for increase) in $O$. anasae.

The $r_{m}$ values for $O$. anasae and $O$. sp. are generally high compared with that of many other insects (see Connell \& Scheiring 1982). However, they are lower than those reported for egg parasitoids in the genera Trichogramma Westwood (Trichogrammatidae) and Telenomus Haliday (Scelionidae) at comparable temperatures (Table 5). Relatively short developmental times and high $R_{0}$ values in Trichogramma, and early reproduction in adult life associated with apparent proövigeny in both genera (see Schwartz \& Gerling 1974, Pak \& Oatman 1982), probably contribute to their low $T$ and high $r$ values. In contrast, the Ooencyrtus species we studied appear to be synovigenic and have somewhat higher $T$ values.

Implications for Biological Control. From our comparative studies (Tracy \& Nechols 1987), a preliminary assessment can be made of the relative potential of $O$. anasae and $O$. sp. for biological control of the SB between 20.8 and $26.6^{\circ} \mathrm{C}$-tem- 
peratures that are in the range of mean temperatures found from late spring to early summer in northeastern Kansas (Kansas State Agricultural Experiment Station 1980).

Although neither parasitoid appears to have a decided advantage at the lower end of the temperature range we tested, $O$. anasae appeared to show a greater increase in the rate of oöcyte production at lower temperatures than $\operatorname{did} O$. sp. In addition, $O$. anasae possessed a clearly higher innate capacity of increase at the highest temperature $\left(26.6^{\circ} \mathrm{C}\right)$. Thus, $O$. anasae may be more amenable to mass production.

Naturally occurring SB egg parasitoids appear to be poorly synchronized with hosts during the early season (Nechols 1987). Thus, O. anasae's ability to respond to slightly lower temperatures may be an advantage should an augmentative release program be developed. Based on our ovipositional data (see Table 1) for mean temperatures during this early season, we conclude that augmentative releases would have to be made at 1 - to 2 -wk intervals to achieve constant field parasitization rates.

Other attributes (e.g., competition, host acceptance, host discrimination, and searching ability) of $O$. anasae and $O$. sp., as well as the basic biology of other egg parasitoids of the SB in Kansas, need to be examined before a full evaluation of this indigenous natural enemy complex can be made. However, the present findings suggest that $O$. anasae may have a relatively greater potential than $O$. sp. for biological control of the SB.

\section{Acknowledgment}

We thank B. J. Willcutts and C. Armendariz (Kansas State University) for technical assistance. We also thank G. Gordh for making parasitoid determinations and for his fine cooperation. We appreciate the helpful suggestions of R. G. Helgesen (Kansas State University), P. L. Mitchell (Tarleton State University), and two anonymous reviewers of earlier drafts of this paper. We thank J. Higgins, J. Boyer, J. Crabb, and J. Pontius (Kansas State University) for statistical assistance. This research was supported by Kansas State Agricultural Experiment Station Hatch Project 546 and by Regional Research Project W-84. This is Contribution No. 88-8-J from the Kansas State Agricultural Experiment Station.

\section{References Cited}

Alzofon, J. 1984. Biology, behavior and life table studies of Ooencyrtus kuvanae Howard (Hymenoptera: Encyrtidae), a gypsy moth egg parasitoid. Ph.D. dissertation, Fordham University, Bronx, N.Y.

Beard, R. L. 1940. The biology of Anasa tristis DeGeer, with particular reference to the tachinid parasite, Trichopoda pennipes Fabr. Connecticut Agricultural Experiment Station Bulletin 440.

Birch, L. C. 1948. The intrinsic rate of increase of an insect population. J. Anim. Ecol. 17: 15-26.

Connell, T. D. \& J. F. Scheiring. 1982. Demography of the shore fly, Scatella picea (Walker) (Diptera: Ephydridae). Environ. Entomol. 11: 611-617.
Crossman, S. S. 1925. Two imported egg parasites of the gypsy moth, Anastatus bifasciatus Fonsc. and Schedius kuvanae Howard. J. Agric. Res. 30: 643675.

DeBach, P., C. B. Huffaker \& A. W. Macphee. 1976. Evaluation of the impact of natural enemies, pp. 255282. In C. B. Huffaker \& P. S. Messenger [eds.], Theory and practice of biological control. Academic, New York.

Fedde, V. H. 1982. Bionomics of the Caribbean bug egg parasite, Ooencyrtus trinidadensis Crawford (Hymenoptera: Encyrtidae). Ph.D. dissertation, North Carolina State University, Raleigh.

Flanders, S. E. 1950. Regulation of ovulation and egg disposal in the parasitic Hymenoptera. Can. Entomol. 82: $134-140$.

Gordh, G. 1977. Biosystematics of natural enemies, pp. 125-148. In R. L. Ridgeway \& S. B. Vinson [eds.], Biological control by augmentation of natural enemies. Plenum, New York.

Herard, F. \& G. Mercadier. 1980. Bionomies comparées de deux souches (Morocaine et Américaine) d'Ooencyrtus kuvanae (Hym.: Encyrtidae), parasite oophage de Lymantria dispar (Lep.: Lymantriidae). Entomophaga 25: 129-137 (in French).

Hirose, Y. 1986. Biological and ecological comparison of Trichogramma as control agents of lepidopterous pests. J. Appl. Entomol. 101: 39-47.

Jervis, M. A. \& N. A. C. Kidd. 1986 . Host-feeding strategies in hymenopteran parasitoids. Biol. Rev. 61: 395-434.

Kansas State Agricultural Experiment Station. 1980. Climatic summary for Manhattan, Kansas. Weather Data Library, Kansas State University, Manhattan.

Laraichi, M. 1978. Influence de la répartition de l'hôte dans le temps sur la fécondité de trois Ooencyrtus (Hym. Encyrtidae), parasites oophages des Punaises des Blés. Ann. Zool. Ecol. Anim. 10: 69-76 (in French).

1979. Etude de quelques facteurs de la fécondité chez Ooencyrtus (Hym. Encyrtidae) parasites oophages des Punaise des Blés: I. Influence de la température. Al-Awamia 57: 121-148 (in French).

Lee, S. C. 1979. Evaluation of Ooencyrtus submetallicus (Howard) and Trissolocus basalis (Wollaston) as egg parasites of Nezara viridula (L.). Ph.D. dissertation, Louisiana State University and Agricultural and Mechanical College, Baton Rouge.

Manweiler, S. A. 1986. Developmental and ecological comparisons of Trichogramma minutum and Trichogramma platneri (Hymenoptera: Trichogrammatidae). Pan-Pac. Entomol. 62: 128-139.

Maple, J. D. 1937. The biology of Ooencyrtus johnsoni (Howard), and the role of the egg shell in the respiration of certain encyrtid larvae (Hymenoptera) Ann. Entomol. Soc. Am. 30: 123-154

1947. Encyrtidae and their adaptations for respiration, pp. 104-105. In University of California Publications in Entomology 8.

Matteson, P. C. 1981. Egg parasitoids of hemipteran pests of cowpea in Nigeria and Tanzania, with special reference to Ooencyrtus patriciae Subba Rao (Hymenoptera: Encyrtidae) attacking Clavigralla tomentosicollis Stàl (Hemiptera: Coreidae). Bull. Entomol. Res. 71: 547-554.

Mendel, M. J., P. B. Shaw \& J. C. Owens. 1987. Lifehistory characteristics of Anastatus semiflavidus (Hymenoptera: Eupelmidae), an egg parasitoid of the range caterpillar, Hemileuca oliviae (Lepidoptera: 
Saturniidae) over a range of temperatures. Environ. Entomol. 16: 1035-1041.

Nechols, J. R. 1987. Voltinism, seasonal reproduction, and diapause in the squash bug (Heteroptera: Coreidae) in Kansas. Environ. Entomol. 16: 269-273.

Orphanides, G. M. \& D. Gonzalez. 1971. Fertility and life table studies with Trichogramma pretiosum and $T$. retorridum (Hymenoptera: Trichogrammatidae). Ann. Entomol. Soc. Am. 64: 824-834.

Orr, D. B. \& D. J. Boethel. 1986. Influence of plant antibiosis through four trophic levels. Oecologia 70 : $242-249$

Orr, D. B., J. S. Russin \& D. J. Boethel. 1986. Reproductive biology and behavior of Telenomus calvus (Hymenoptera: Scelionidae), a phoretic egg parasitoid of Podisus maculiventris (Hemiptera: Pentatomidae). Can. Entomol. 118: 1063-1072.

Pak, G. A. \& E. R. Oatman. 1982. Comparative life table, behavior and competition studies of Trichogramma brevicapillum and T. pretiosum. Entomol. Exp. Appl. 32: 68-69.

Pielou, E. C. 1977. Mathematical ecology. Wiley, New York.

Price, P. W. 1984. Life histories and reproductive strategies, pp. 235-260. In P. W. Price [ed.], Insect ecology. Wiley, New York.

SAS Institute. 1985a. SAS user's guide: basics. SAS Institute, Cary, N.C.

$1985 \mathrm{~b}$. SAS user's guide: statistics. SAS Institute, Cary, N.C.

Schwartz, A. \& D. Gerling. 1974. Adult biology of Telenomus remus (Hymenoptera: Scelionidae) under laboratory conditions. Entomophaga 19: 483-492.

Stearns, S. C. 1980. A new view of life-history evolution. Oikos 35: 266-281.

Tauber, C. A. \& M. J. Tauber. 1982. Evolution of seasonal adaptations and life history traits in Chrysopa: response to diverse selective pressures, pp. 5172. In H. Dingle \& J. P. Hegmann [eds.], Evolution and genetics of life histories. Springer-Verlag, New York.

1987. Food specificity in predacious insects: a comparative ecophysiological and genetic study. Evol. Ecol. 1: 175-186.
Tauber, M. J., C. A. Tauber \& S. Masaki. 1986. Seasonal adaptations of insects. Oxford University, New York.

Tracy, J. L. 1987. Biological comparisons between the squash bug egg parasitoids, Ooencyrtus anasae (Ashmead) and O. sp. (Hymenoptera: Encyrtidae): a laboratory assessment. M.S. thesis, Kansas State University, Manhattan.

Tracy, J. L. \& J. R. Nechols. 1987. Comparisons between the squash bug egg parasitoids Ooencyrtus anasae and $O$. sp. (Hymenoptera: Encyrtidae): development, survival and sex ratio in relation to temperature. Environ. Entomol. 16: 1324-1329.

van Lenteren, J. C. \& A. W. van der Schaal. 1981. Temperature thresholds for oviposition of Encarsia formosa, Encarsia tricolor and Encarsia pergandiella in larvae of Trialeurodes vaporariorum. Meded. Fac. Landbouwwet. Rijksuniv. Gent 46: 457-464.

van Lenteren, J. C., A. van Vianen, H. F. Gast \& A. Kortenhoff. 1987. The parasite-host relationship between Encarsia formosa Gahan (Hymenoptera: Aphelinidae) and Trialeurodes vaporariorum (Westwood) (Homoptera: Aleyrodidae). XVI. Food effects on oogenesis, oviposition, life-span and fecundity of Encarsia formosa and other hymenopterous parasites. J. Appl. Entomol. 103: 69-84.

Waage, J. K. \& S. M. Ng. 1984. The reproductive strategy of a parasitic wasp. I. Optimal progeny and sex allocation in Trichogramma evanescens. J. Anim. Ecol. 53: 401-415.

Weseloh, R. M. 1986. Effect of photoperiod on progeny production and longevity of gypsy moth (Lepidoptera: Lymantriidae) egg parasite Ooencyrtus $\mathrm{ku}$ vanae (Hymenoptera: Encyrtidae). Environ. Entomol. 15: $1149-1153$

Williams, D. W. 1984. Ecology of a blackberry-leafhopper-parasite system and its relevance to California grape agroecosystems. Hilgardia 52: 1-32.

Received for publication 27 July 1987; accepted 29 February 1988. 